\title{
Catalytic Hydrogenation Reactions on Molybdenum Oxide
}

\author{
H. Al-Kandari', S. Al-Kandari'2, A. M. Mohamed'2, F. Al-Kharafi'2, A. Katrib²* \\ ${ }^{1}$ College of Health Sciences, PAAET, Faiha, Kuwait \\ ${ }^{2}$ Chemistry Department, Kuwait University, Safat, Kuwait \\ Email: ${ }^{*}$ ali.katrib@ku.edu.kw
}

Received 19 November 2014; revised 14 December 2014; accepted 6 January 2015

Copyright (C) 2015 by authors and Scientific Research Publishing Inc.

This work is licensed under the Creative Commons Attribution International License (CC BY). http://creativecommons.org/licenses/by/4.0/

(c) (i) Open Access

\begin{abstract}
Partially reduced molybdenum trioxide deposited on titania under hydrogen at $673 \mathrm{~K}$ for $12 \mathrm{~h}$ enabled to convert several surface atomic layers to the catalytically active bifunctional (metal-acid) $\mathrm{MoO}_{2-\mathrm{x}}(\mathrm{OH})_{\mathrm{y}} / \mathrm{TiO}_{2}$ (MoTi) structure. The formed metallic function is the result of $\pi$ bonding between adjacent Mo-Mo atoms placed along the $\mathrm{C}$-axis of the rutile structure of $\mathrm{MoO}_{2}$. Delocalization of these $\pi$ electrons produces a wire like atomic metal. This resembles in a way, the small Pt particles deposited on a support. Moreover, dissociated hydrogen atoms are bonded to sample surface oxygen to produce Brønsted acid Mo-OH function(s). These metal-acidic properties have been tested for several catalytic reactions requiring one or bothcatalytic functions. In this order, 2-propanol species could be considered as a model test of the acidic function via dehydration of the molecule to propene, while hydrogenation of the produced propene to propane is performed by the metallic function. Moreover, hydrogenation of 2-propanol to acetone, requires relatively strong metallic function. In this order, addition of small amount of alkali metal like rubidium will suppress the acidic function in $\mathrm{MoO}_{2-\mathrm{x}}(\mathrm{OH})_{\mathrm{y}} / \mathrm{TiO}_{2}$ and enhance the metallic function strength. The performance of the metallic function alone in this case will be evaluated. Titanium dioxide is employed in this catalytic system as a support. It does not have any catalytic effect. Association of XPS-UPS, ISS surface techniques with catalytic performances of this catalytic MoTi system will be presented.
\end{abstract}

\section{Keywords}

$\mathrm{MoO}_{2-\mathrm{x}}(\mathrm{OH})_{\mathrm{y}}$ Catalyst, XPS, Acid-Metal Functions, Hydrogenation, 2-Propanol

\section{Introduction}

Hydroisomerization and hydrogenation reactions of light naphtha compounds are of special interest in terms of improving the octane number of these compounds [1]. In general, these catalytic reactions are carried out using

${ }^{*}$ Corresponding author.

How to cite this paper: Al-Kandari, H., Al-Kandari, S., Mohamed, A.M., Al-Kharafi, F. and Katrib, A. (2015) Catalytic Hydrogenation Reactions on Molybdenum Oxide. Modern Research in Catalysis, 4, 36-42.

http://dx.doi.org/10.4236/mrc.2015.41005 
finely dispersed noble metals such as Pd, Pt, Rh [2]-[5]. Hydroisomerization process of these compounds requires both the metallic and acidic functions. Several problems are encountered using these noble metals based systems such as highly dispersed fine particles preparation, sintering and poisoning by sulfur and other trace metals. A molybdenum oxide based catalyst of bifunctional (metal-acid) $\mathrm{MoO}_{2-\mathrm{x}}(\mathrm{OH})_{\mathrm{y}} / \mathrm{TiO}_{2}(\mathrm{MoTi})$ properties has been prepared [6]-[8]. Controlled reduction by hydrogen of $\mathrm{MoO}_{3}$ deposited on $\mathrm{TiO}_{2}$ at $673 \mathrm{~K}$ results in the partial reduction of $\mathrm{MoO}_{3}$ to $\mathrm{MoO}_{2}$, characterized by in-situ XPS-UPS techniques. The metallic properties of this system are attributed to the delocalized $\pi$ bonding between adjacent Mo atoms placed along the C-axis of the deformed rutile structure of $\mathrm{MoO}_{2}$ [Jones]. The specific morphology of these metallic-like $\pi$ electrons is comparable to the metallic properties of finely dispersed Pt or Pd-nanoparticles. Furthermore, hydrogen molecules are dissociated by this metallic function. Consequently, bonding of the hydrogen atoms to surface oxygens results in the formation of Brønsted acid Mo-OH function(s). Both metallic and acidic sites are present on the catalyst surface. This is to be compared of commonly prepared bifunctional catalysts using the metallic properties of noble metals deposited on acidic supports such as zeolites or $\mathrm{Al}_{2} \mathrm{O}_{3}$. In this catalytic $\mathrm{MoO}_{2-\mathrm{x}}(\mathrm{OH})_{\mathrm{y}} / \mathrm{TiO}_{2}$ system, $\mathrm{TiO}_{2}$ support provides larger surface area to the Mo phase and mechanical strength to the catalyst.

In this research work, we provide some catalytic hydrogenation reactions of C5-C7 alkenes. The catalytic performances of both acidic and metallic functions in terms of dehydration/hydrogenation of 2-propanol will be presented. Suppression of the Brønsted acid Mo-OH function(s) is achieved by the addition of controlled amount of alkali metal such as $\mathrm{K}$ or $\mathrm{Rb}$.

\section{Experimental}

\subsection{Catalyst Preparation}

The equivalent of 5 monolayers of molybdenum trioxide were deposited on $\mathrm{TiO}_{2}$ using ammonium heptamolybdate $\left(\mathrm{NH}_{4}\right)_{6} \mathrm{Mo}_{7} \mathrm{O}_{24} \cdot 4 \mathrm{H}_{2} \mathrm{O}$ (99.9\%) supplied by STREM Chemicals. Titanium dioxide, $\mathrm{TiO}_{2}$, is Degussa P-25 (25\% rutile) with a pore volume of $0.5 \mathrm{~cm}^{3} / \mathrm{g}$ and a BET surface area of $50 \pm 5 \mathrm{~m}^{2} / \mathrm{g}$. Supported catalysts are prepared by impregnating the appropriate amount of molybdenum in ammonium heptamolybdate salt following the method described by Pines et al. [9]. After impregnation, the catalyst is calcined at $773 \mathrm{~K}$ which enabled to convert the molybdenum compound to $\mathrm{MoO}_{3}$ as characterized by XPS. Small amount of $2.5 \%$ by mass of rubidium with respect to Mo were added to the impregnated catalyst. Catalyst activation is achieved following insitu reduction of the $\mathrm{MoO}_{3} / \mathrm{TiO}_{2}$ system in a flow of $40 \mathrm{~cm}^{3} \mathrm{H}_{2} / \mathrm{min}$. was carried out at $673 \mathrm{~K}$. The hydrogen gas was a $99.9 \%$ pure product of KOAC (Kuwait).

\subsection{Catalyst Characterization}

Characterization of the samples by XPS was conducted using VG Scientific ESCALAB-250Xi spectrometer. The radiation source was monochromatic of $\mathrm{Al} \mathrm{K} \alpha$ operating at a power of $300 \mathrm{~W}$ (15 kV, $20 \mathrm{~mA}$ ). UPS $\mathrm{He}(\mathrm{I})$ resonance $584 \AA$ radiation of $21.217 \mathrm{eV}$ was employed for the VB energy region measurements. Vacuum in the analysis chamber was below $7 \times 10^{-9}$ mbar during all measurements. In-situ reduction was carried out in a high-pressure gas cell housed in the preparation chamber, with hydrogen flow at $120 \mathrm{~mL} / \mathrm{min}$. Binding energies were based on the carbon contamination C1s at $284.8 \mathrm{eV}$ within an experimental error of $\pm 0.2 \mathrm{eV}$.

Ion scattering measurements were performed on the same sample using $\mathrm{He}^{+}$with a kinetic energy of $1 \mathrm{KeV}$.

\subsection{Catalyst Tests}

Time on stream catalytic reactions under atmospheric hydrogen pressure was studied. The reactant was drawn from the reservoir throw HPLC pump of flow rate of $0.1 \mathrm{ml} / \mathrm{min}$ then it passed though vaporizer and eventually it passed over a fixed bed quartz reactor containing the catalyst. A continuous $\mathrm{H}_{2}$ flow of $40 \mathrm{~cm}^{3} / \mathrm{min}$ was allowed through $500 \mathrm{mg}$ of the catalyst which contains $65 \mathrm{mg}$ of Mo. The reaction mixture was separated and analyzed with an on-line gas chromatograph Chemito, India 1000 equipped with a Petrocol-DH column and a flame ionization detector.

\section{Results and Discussion}

\subsection{XPS-UPS, ISS Catalyst Characterization}

X-ray photoelectron spectroscopy XPS, UPS and Ion Scattering ISS techniques are the most appropriate surface 
techniques which enable to define the nature and composition of the outermost surface layers, responsible for the catalytic activity of a system. Characterization experiments were carried out in-situ at the same conditions of catalytic measurements. The assignment of the different oxidation states of Mo oxides is based on the Mo $\left(3 \mathrm{~d}_{3 / 2}\right.$, 5/2) spin-orbit components. These energies are at 235.85, $232.65 \mathrm{eV}$ for $\mathrm{MoO}_{3}, 234.9,231.7 \mathrm{eV}$ for $\mathrm{Mo}_{2} \mathrm{O}_{5}$ and 232.3, $229.1 \mathrm{eV}$ for $\mathrm{MoO}_{2}$. Continuous sample exposure to hydrogen as a function of reduction temperature results in the formation of large Mo (0) crystallites at $873 \mathrm{~K}$. This metallic state of Mo is characterized by Mo(3d) spin-orbit components at 230.85 and $227.7 \mathrm{eV}$.

Two well-defined spectral lines at 235.9 and $232.7 \mathrm{eV}$ were observed (Figure 1(a)) in the case of calcined Mo salt deposited on $\mathrm{TiO}_{2}$. These lines are assigned to the Mo (3d) spin-orbit components of $\mathrm{MoO}_{3}$. In situ exposure of the sample to hydrogen at $673 \mathrm{~K}$ for $12 \mathrm{~h}$ shows the presence of more complex structure of the Mo (3d) energy region (Figure 1(b)). Deconvolution of this band reveals the presence of three Mo oxides states. The most intense $\mathrm{Mo}\left(3 \mathrm{~d}_{3 / 2}, 5 / 2\right)$ at 232.3 and $229.1 \mathrm{eV}$ is assigned to $\mathrm{MoO}_{2}$. Lower concentration states of $\mathrm{Mo}_{2} \mathrm{O}_{5}$ and $\mathrm{MoO}_{3}$ are also present. Most probably, the $\mathrm{MoO}_{2}$ structure constitutes the outermost surface structure of the sample. This statement is based on the fact that the XPS of the valence band following sample reduction at 673 K (Figure 2(b)) reveals the presence of DOS structure at the Fermi level, characteristic of the conductive $\pi$ electrons of $\mathrm{MoO}_{2}$. This DOS structure $(0.4 \mathrm{eV})$ at the surface of the sample is well defined in the UP spectrum (Figure 3(b)). Consequently, it is concluded that $\mathrm{Mo}_{2} \mathrm{O}_{5}$ is present in the interphase between surface $\mathrm{MoO}_{2}$ and unreduced $\mathrm{MoO}_{3}$ in the bulk.

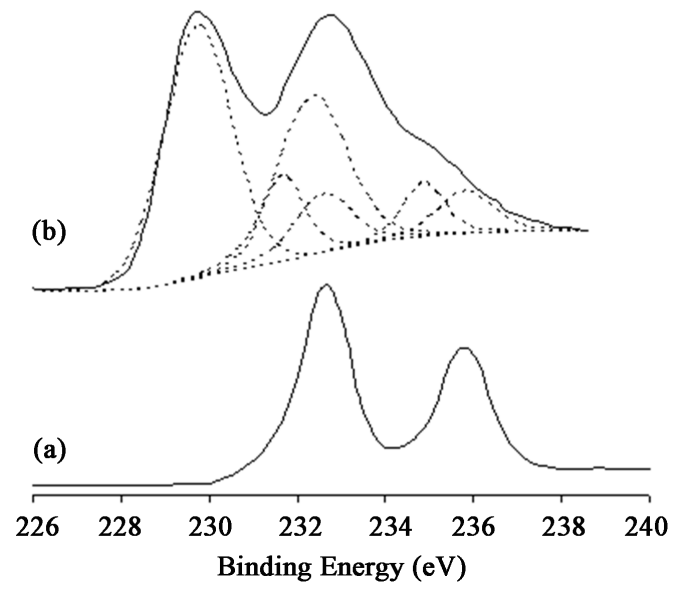

Figure 1. $\mathrm{Mo}(3 \mathrm{~d})$ region of $\mathrm{MoO}_{3} / \mathrm{TiO}_{2} 5$ layers (a) before treatment (b) after reduction at $673 \mathrm{~K}$ for $12 \mathrm{~h}$.

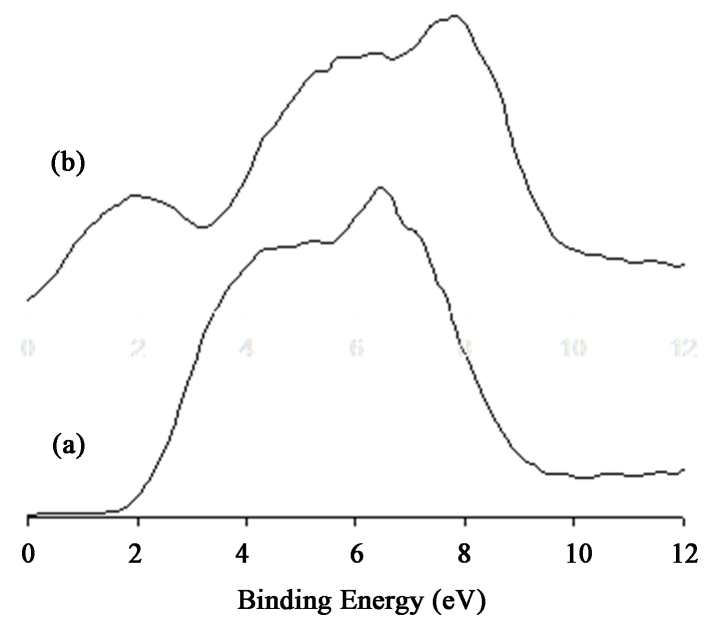

Figure 2. XPS of the valence band of 5 layers $\mathrm{MoO}_{3} / \mathrm{TiO}_{2}$ (a) before treatment (b) after reduction at $673 \mathrm{~K}$ for $12 \mathrm{~h}$. 


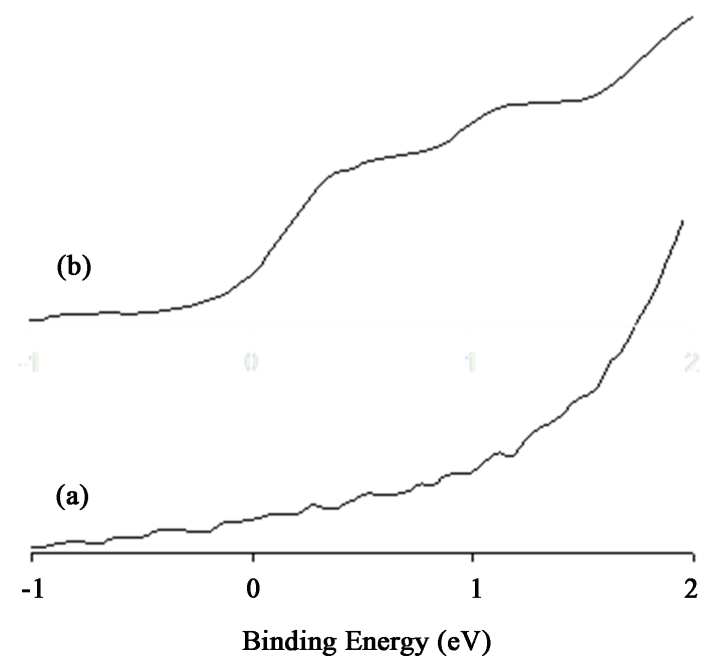

Figure 3. UPS of 5 layers $\mathrm{MoO}_{3} / \mathrm{TiO}_{2}$ (a) before treatment (b) after reduction at $673 \mathrm{~K}$ for $12 \mathrm{~h}$.

In the case of the reduced sample by hydrogen at $673 \mathrm{~K}$ (Figure 4(b)), the oxygen $1 \mathrm{~s}$ energy region shows the presence of a shoulder at $531.4 \mathrm{eV}$ beside the main oxide oxygen. This is attributed to the formation of Brønsted acid Mo-OH function(s) on the sample surface. The Mo-OH formation takes place in a sequent of processes in which hydrogen molecules were dissociated by the delocalized $\pi$ electrons to hydrogen atoms. Bonding of the produced active hydrogen atoms to surface oxygen results in the formation of Brønsted acid Mo-OH groups. As a result, a bifunctional $\mathrm{MoO}_{2-\mathrm{x}}(\mathrm{OH})_{\mathrm{y}} / \mathrm{TiO}_{2}$ structure is obtained.The XPS of the Ti 2p energy region before and after hydrogen reduction does not show any changes in neither the binding energy nor the spectral lines shape (Figure 5(a) and Figure 5(b)). In fact, $\mathrm{TiO}_{2}$ is employed in this case as a support in order to increase the surface area and provide mechanical strength to the Mo catalyst. ISS spectra of the Mo sample shows the presence of Mo, Ti and oxygen on the sample surface before and after reduction (Figure 6(a) and Figure 6(b)). This indicates that Mo does not completely cover the $\mathrm{TiO}_{2}$ surface, This is due, most probably to the formation of needle like crystallite structure of $\mathrm{Mo}$ on $\mathrm{TiO}_{2}$ as observed by Bond et al. [10].

\subsection{Catalytic Measurements}

Hydrogenation catalytic reactions of C5 - C7 alkenes and dehydration/ hydrogenation of 2-propanol will be presented.

\subsubsection{1-Pentene}

Complete conversion of 1-pentene to n-pentane takes place on the bifunctional $\mathrm{MoO}_{2-\mathrm{x}}(\mathrm{OH})_{\mathrm{y}} / \mathrm{TiO}_{2}$ at $423 \mathrm{~K}$ (Figure 7). Although the conversion remains unchanged at higher reaction temperatures, isomerization of the produced pentane to isopentane takes place. At $623 \mathrm{~K}, 54.9 \%$ of the hydrogenated n-pentane molecules undergo isomerization to iso-pentane via carbenium ion mechanism requiring both metal-acid functions [11]. At higher reaction temperature, hydrocracking reactions producing C1-C3 hydrocarbon species are favored. It is interesting to note that different catalytic behavior takes place using large Mo (0) crystallites. Hydrocraking C1-C3 products are dominant. Also, no isomerization process to i-C5 is observed. This is attributed, in part, to the relatively strong metallic function in Mo (0). Isomerization to iso-pentane cannot be performed due to the absence of the acidic function. Similar catalytic behavior to Mo (0) has been observed in the case of the addition of trace alkali metals such as $\mathrm{K}, \mathrm{Rb}$, Cs to the molybdenum oxide and reduced at $673 \mathrm{~K}$. The promoter alkali metal in this case suppress the Brønsted acid Mo-OH in favor of Mo-OA $(\mathrm{A}=\mathrm{Rb})$.

\subsubsection{1-Hexene}

In similar way to what is observed in the case of 1-pentene, complete hydrogenation of 1-hexene molecules to nhexane over $\mathrm{MoO}_{2-\mathrm{x}}(\mathrm{OH})_{\mathrm{y}} / \mathrm{TiO}_{2}$ takes place at $423 \mathrm{~K}$. However, at higher reaction temperature, part of the produced n-hexane molecules are isomerized to mainly 2 and 3-methylhexane with a ratio $2 \mathrm{MP} / 3 \mathrm{MP}=1.5$ in 


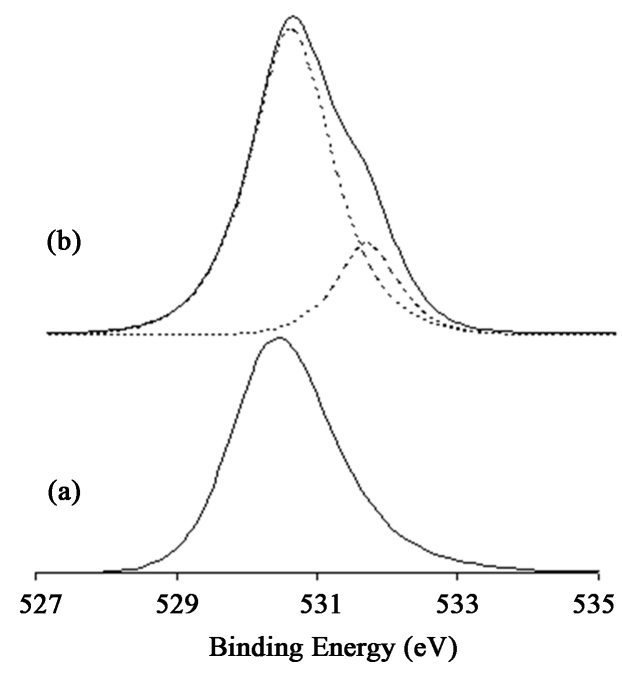

Figure 4. O1s region of 5 layers $\mathrm{MoO}_{3} / \mathrm{TiO}_{2}$ (a) before treatment (b) after reduction at $673 \mathrm{~K}$ for $12 \mathrm{~h}$.

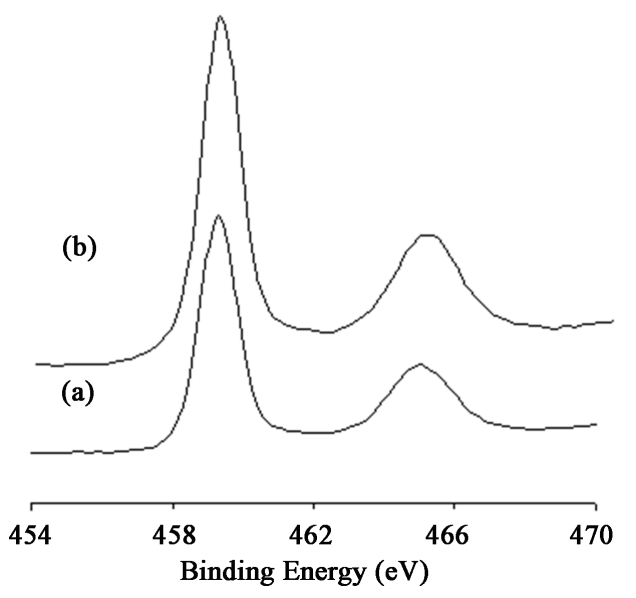

Figure 5. Ti 2P region of 5 layers $\mathrm{MoO}_{3} / \mathrm{TiO}_{2}$ (a) before treatment (b) after reduction at $673 \mathrm{~K}$ for $12 \mathrm{~h}$.

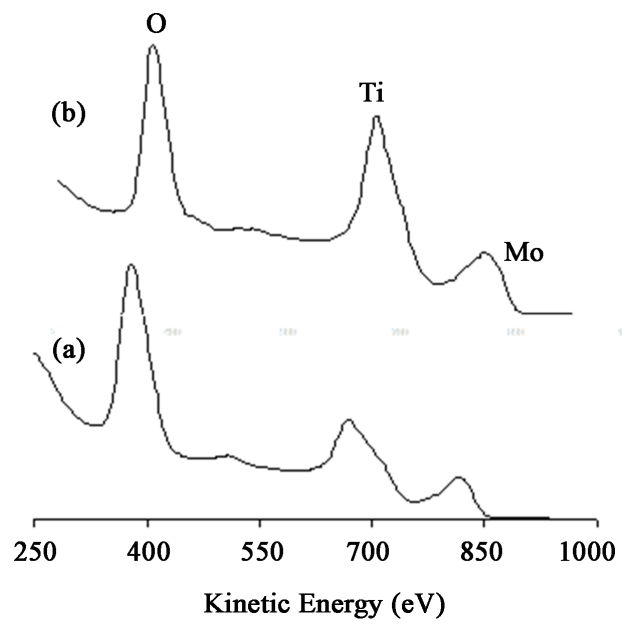

Figure 6. ISS of 5 layer $\mathrm{MoO}_{3} / \mathrm{TiO}_{2}$ (a) before treatment (b) after reduction at $673 \mathrm{~K}$ for $12 \mathrm{~h}$. 


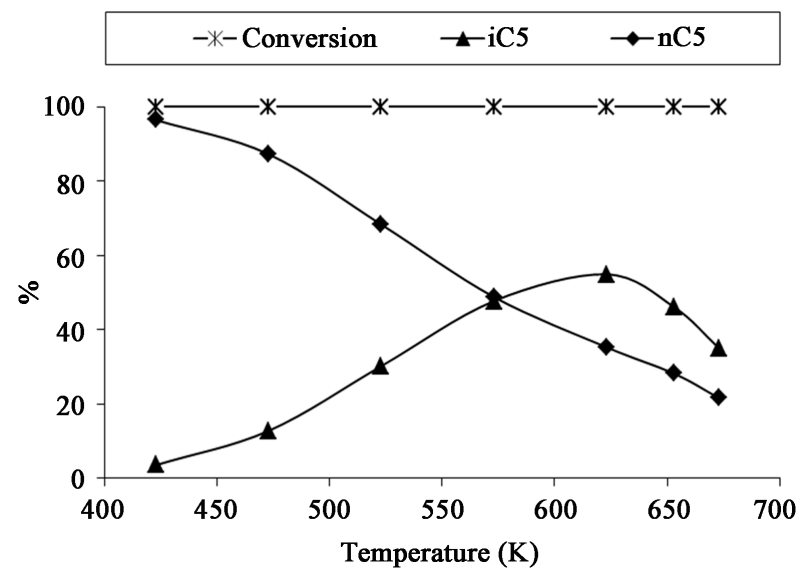

Figure 7. Hyrogenation and isomerization of 1-pentene on $\mathrm{MoO}_{2-\mathrm{x}}(\mathrm{OH})_{\mathrm{v}} / \mathrm{TiO}_{2}$ as a function of reaction temperature.

agreement with the thermodynamic ratio. Also and to lesser extent, 2,2 and 2,3 dimethylbutanesisomerizations products were obtained. Beyond $623 \mathrm{~K}$ reaction temperature, hydrocracking products are favored.

\subsubsection{1-Heptene}

Although complete hydrogenation of 1-heptene to heptane takes place at $423 \mathrm{~K}$, in similar way to 1-pentene and 1-hexene catalytic reactions, considerable decrease in the hydrogenation process in favor of hydrocracking products at higher reaction temperature of $523 \mathrm{~K}$ is observed. This is due, most probably, to the size of the heptene molecule. Hydroisomerization of 1-heptene to mainly 2 and 3-methylhexanes with ratio $2 \mathrm{MH} / 3 \mathrm{MH}$ is close to unity is observed. The selectivity of these isomers reach a maximum of $45 \%$ at $573 \mathrm{~K}$ reaction temperature. These catalytic results clearly demonstrate that concerted sequences of catalytic process in terms of hydrogenation followed by isomerization reactions (dehydrogenation/isomerization of the olefin/hydrogenatio take place on this bifunctional Mo oxide catalyst.

\subsubsection{2-Propanol}

The catalytic behavior of 2-propanol is generally used to determine the redox properties of oxide catalysts [12]. In this respect, three reactions could take place depending on the nature and strengths of the catalyst active sites. Dehydration of 2-propanol to propene is performed by the acidic site [13] [14]. On the other hand, hydrogenation of the produced propene to propane is performed by metallic function. More difficult dehydrogenation of 2-propanol to acetone is performed by a metallic function of certain strength. Complete conversion of 2-propanol to propene takes place at $423 \mathrm{~K}$ using the bifunctional $\mathrm{MoO}_{2-\mathrm{x}}(\mathrm{OH})_{\mathrm{y}} / \mathrm{TiO}_{2}$ system. This conversion remains total at higher temperatures up to $673 \mathrm{~K}$. However, at $523 \mathrm{~K}, 11.6 \%$ of the formed propene molecules are hydrogenated to propane. This hydrogenation process increases as a function of the reaction temperature to reach $81.7 \%$ at $673 \mathrm{~K}$. The concerted dehydration/hydrogenation process is clearly demonstrated in this case. This is in agreement with the surface characterization of the $\mathrm{MoO}_{2-\mathrm{x}}(\mathrm{OH})_{\mathrm{y}} / \mathrm{TiO}_{2}$ system as a bifunctional (metal-acid) system. Dehydrogenation of 2-propanol to acetone was not observed in this Mo system. However, addition of small amount (2.5\%) of $\mathrm{Rb}$ to the $\mathrm{MoO}_{3} / \mathrm{TiO}_{2}$ after calcination enabled to obtain $47 \%$ of acetone at $473 \mathrm{~K}$ reaction temperature. In this $\mathrm{Rb}$ modified system, a drastic decrease in the dehydration/hydrogenation processes takes place. This is due to the suppression of the acidic function by the alkali metal addition. The catalytic activity and stability of this system has been tested for several days, time on stream experiments without any observed changes in its performances. Extended research for other catalytic reactions is underway.

The above data clearly demonstrate the excellent concordance of catalytic activity-surface XPS-UPS, ISS characterization techniques in identifying the type and, to some extent, the relative strength of the catalytic active sites in a given system.

\section{Conclusions}

In situ XPS-UPS, ISS surface characterization enabled to define the chemical state of Mo following the calcina- 
tion at $773 \mathrm{~K}$ of ammonium heptamolybdate deposited on $\mathrm{TiO}_{2}$, It was found that the calcination process at 773 $\mathrm{K}$ of both systems enabled to convert all Mo salt to $\mathrm{MoO}_{3}$ state. However, in-situ hydrogen reduction results in partial conversion of $\mathrm{MoO}_{3}$ to $\mathrm{MoO}_{2}$ in the case of $\mathrm{MoO}_{3} / \mathrm{TiO}_{2}$. The molybdenum dioxide is present in form of bifunctional (metal/acid) $\mathrm{MoO}_{2-\mathrm{x}}(\mathrm{OH})_{\mathrm{y}} / \mathrm{TiO}_{2}(\mathrm{MoTi})$ structure. The acidic function could be suppressed by the addition of small amount of an alkali metal such as rubidium.

The bifunctional catalytic properties of MoTi and the only metallic properties of the modified system were evaluated for the hydrogenation catalytic reactions of C5 - C7 linear alkenes and 2-propanol. Complete hydrogenation takes place at $423 \mathrm{~K}$, followed by hydroismerization processes performed by the metal-acid functions of the catalyst. Dehydration of 2-propanol to propene is the easiest catalytic process performed by the Mo-OH acidic function, followed by the hydrogenation of the produced olefin to alkane, is performed by the metallic function of the system. Dehydrogenation of 2-propanol to acetone was not observed using Mo oxide catalyst alone. It required the addition of small concentration of $\mathrm{Rb}$ to initiate this reaction at $423 \mathrm{~K}$.

\section{Acknowledgements}

The support by Kuwait University through research grant \# SC01/13 and GFS project \# GS02/08 is gratefully acknowledged.

\section{References}

[1] Ghosh, P., Hickey, K.J. and Jaffe, S.B. (2005) Development of a Detailed Gasoline Composition-Based Octane Model. Industrial \& Engineering Chemistry Research, 45, 337-345. http://dx.doi.org/10.1021/ie050811h

[2] Martino, G. (2001) Conversion Processes. Editions Technip, Paris, 101.

[3] Bond, G.C., Garin, F. and Maire, G. (1988) Characterization of the Standard Platinum/Silica Catalyst EUROPT-1: VI. Catalytic Properties. Applied Catalysis, 41, 313-335. http://dx.doi.org/10.1016/S0166-9834(00)80401-7

[4] Chica, A. and Corma, A. (1999) Hydroisomerization of Pentane, Hexane, and Heptane for Improving the Octane Number of Gasoline. Journal of Catalysis, 187, 167-176. http://dx.doi.org/10.1006/jcat.1999.2601

[5] Kimura, T. (2003) Development of $\mathrm{Pt} / \mathrm{SO}_{4}{ }^{2-} / \mathrm{ZrO}_{2}$ Catalyst for Isomerization of Light Naphtha. Catalysis Today, 81, 57-63. http://dx.doi.org/10.1016/S0920-5861(03)00102-0

[6] Al-Kandari, H., Al-Kandari, S., Al-Kharafi, F. and Katrib, A. (2009) Molybdenum-Based Catalysts for Upgrading Light Naphtha Linear Hydrocarbon Compounds. Energy \& Fuels, 23, 5737-5742. http://dx.doi.org/10.1021/ef900617d

[7] Al-Kandari, H., Mohamed, A.M., Al-Kandari, S., Al-Kharafi, F., Mekhemer, G.A., Zaki, M.I. and Katrib, A. (2013) Spectroscopic Characterization-Catalytic Activity Correlation of Molybdena Based Catalysts. Journal of Molecular Catalysis A: Chemical, 368-369, 1-8. http://dx.doi.org/10.1016/j.molcata.2012.11.013

[8] Al-Kandari, S., Al-Kandari, H., Mohamed, A.M., Al-Kharafi, F. and Katrib, A. (2014) Tailoring Acid-Metal Functions in Molybdenum Oxides: Catalytic and XPS-UPS, ISS Characterization Study. Applied Catalysis A: General, 475, 497502. http://dx.doi.org/10.1016/j.apcata.2014.02.006

[9] Pines, H., Olberg, R.C. and Ipatieff, V.N. (1948) Studies in the Terpene Series. VIII.1 Effect of Catalyst, Solvent and Temperature on the Dehydrogenation of Pinane and p-Menthane2. Journal of the American Chemical Society, 70, 533537. http://dx.doi.org/10.1021/ja01182a031

[10] Bond, G.C., Flamerz, S. and VanWijk, L. (1987) Structure and Reactivity of Titania-Supported Molybdenum and Tungsten Oxides. Catalysis Today, 1, 229-243. http://dx.doi.org/10.1016/0920-5861(87)80042-1

[11] Gault, F.G. (1981) Mechanisms of Skeletal Isomerization of Hydrocarbons on Metals. Advances in Catalysis, 30, 1-95. http://dx.doi.org/10.1016/S0360-0564(08)60325-9

[12] Haffad, D., Chambellan, A. and Lavalley, J.C. (2001) Propan-2-ol Transformation on Simple Metal Oxides $\mathrm{TiO}_{2}$, $\mathrm{ZrO}_{2}$ and $\mathrm{CeO}_{2}$. Journal of Molecular Catalysis A: Chemical, 168, 153-164. http://dx.doi.org/10.1016/S1381-1169(00)00516-1

[13] Bautista, F.M., Campelo, J.M., GarciA, A., Luna, D., Marinas, J.M., Romero, A.A. and Siles, M.T. (2003) VanadylAluminum Binary Phosphate: Al/V Ratio Influence on Their Structure and Catalytic Behavior in the 2-Propanol Conversion. Catalysis Today, 78, 269-280. http://dx.doi.org/10.1016/S0920-5861(02)00352-8

[14] Toda, Y., Ohno, T., Hatayama, F. and Miyata, H. (1999) Effect of $\mathrm{WO}_{3}$ in Mixed $\mathrm{V}_{2} \mathrm{O}_{5}-\mathrm{WO}_{3} / \mathrm{ZrO}_{2}$ Catalysts on Their Surface Structures and Decomposition of Propan-2-ol. Physical Chemistry Chemical Physics, 1, 1615-1621. http://dx.doi.org/10.1039/a809536a 
Scientific Research Publishing (SCIRP) is one of the largest Open Access journal publishers. It is currently publishing more than 200 open access, online, peer-reviewed journals covering a wide range of academic disciplines. SCIRP serves the worldwide academic communities and contributes to the progress and application of science with its publication.

Other selected journals from SCIRP are listed as below. Submit your manuscript to us via either submit@scirp.org or Online Submission Portal.
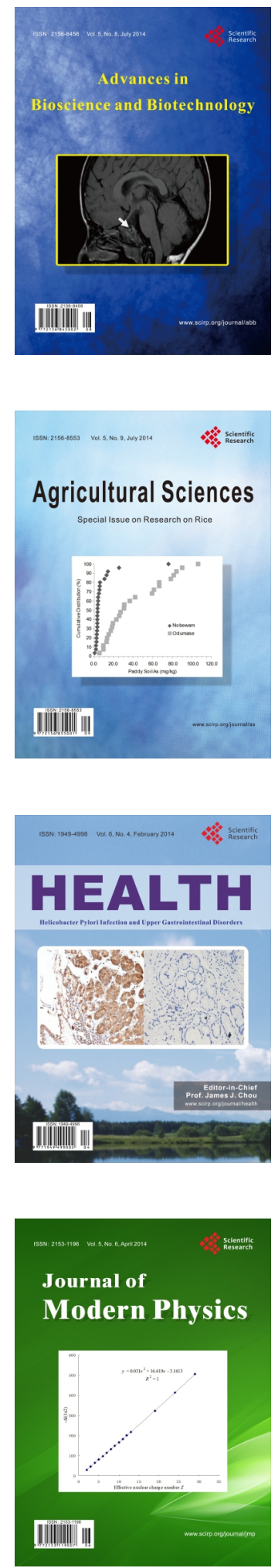
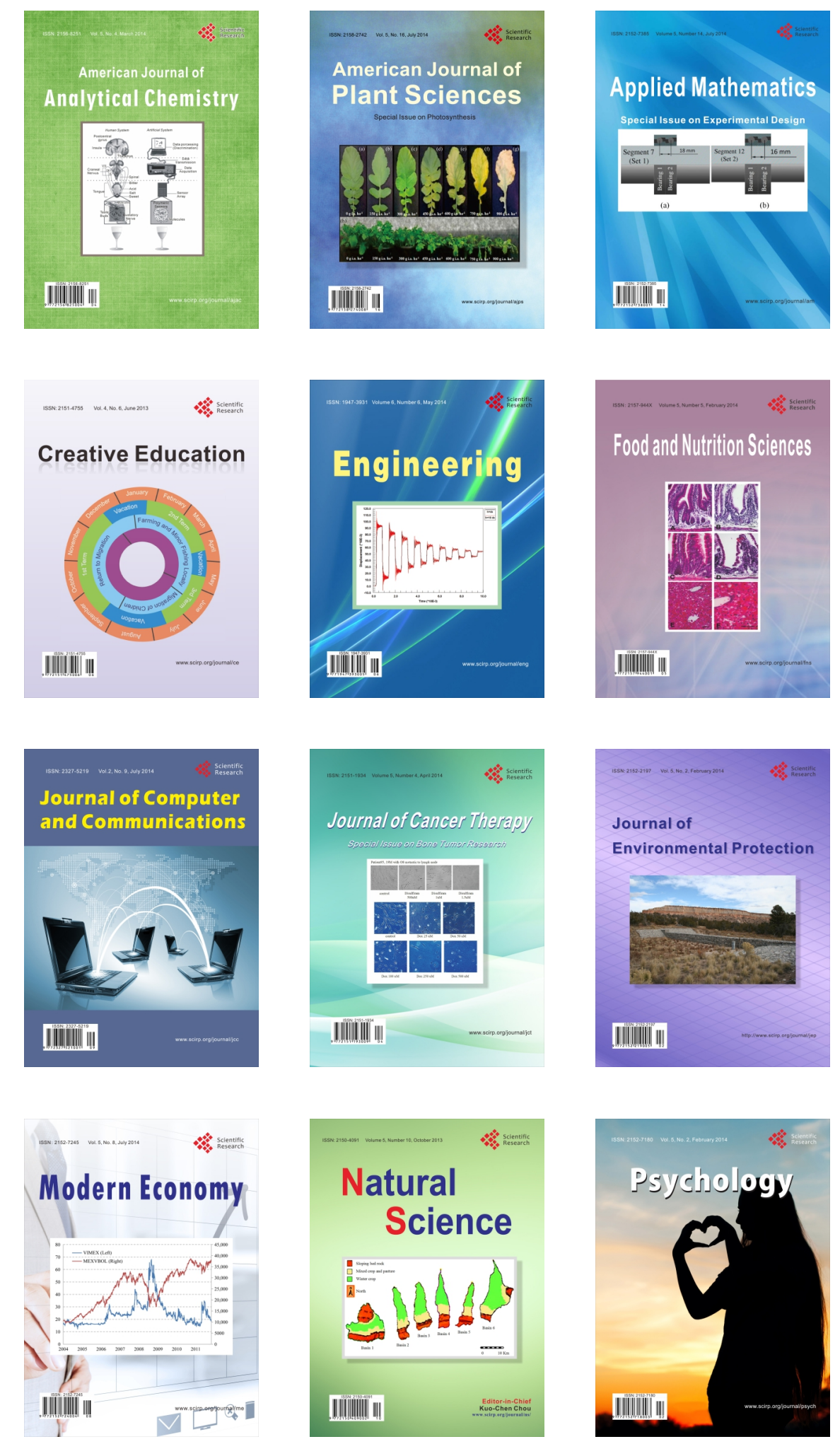